Leptogaster loewi sp. nov.

Similar to L. favillaceus and L. flavipes. Legs pale; hind femora with traces of a dark band over swollen part, tip of hind tibiæ dark. Antennæ yellow; thorax grayish brown above, with traces of median stripes, the two bristles each side black; abdomen grayish brown, tips of third, fourth, and fifth segments yellowish; venation yellowish-brown, as in L. flavipes.

Differs from $L$. flavipes (and favillaceus) in lacking pale on abdomen before middle of segments, and the more distinct band on hind femora. Length, 10-12 mm.

From Paeonian Springs, Va., 28 June, and Ithaca, N. Y., 7 July.

\title{
NOTES ON AULACOPHORA OLIVIER AND OIDES
} WEBER.

\section{By F. C. Bowditch,} Brookline, Massachusetts.

In the arrangement of my Austral-Malayan species of Aulacophora the following notes occur which may aid in the study of this group.

In Mr. Baly's table of males, Linn. Soc. Journ. vol. xx, p. 2, No. 14 postica Chap. is placed in $\S \mathrm{A}_{{ }_{\mathrm{B}}}$ : it should be in $\S \mathrm{A}_{\mathrm{A}}$ having the middle anal segment sulcate longitudinally, as stated by him in the description, p. 12, and verified by examination.

Unicolor Jac. cited by Baly l. c., p. 23, states that the $\sigma^{7}$ is unknown; the description by Mr. Jacoby, Notes Leyden Mus. vol. v, p. 201, speaks of five specimens, all $q$ 's; one of these five examples in the first Jacoby collection is now before me and is a $\sigma^{7}$ : the middle lobe of the anal segment is slightly concave, placing it in $\S \mathrm{A}_{{ }_{\mathrm{B}}}$ of Baly's table of $\mathrm{o}^{\text {' }} \mathrm{s}$. Mr. Baly speaks of its resemblance to Boisduvali but the anal sulcation seems to me to differ somewhat and needs further comparison. If the two are identical it seems that intermediate forms must occur and $I$ have seen none.

Semilimbata Baly described 1. c., p. 74, has no characters given for the $\sigma^{\top}$; the type specimen apparently came from "New Guinea, (Wallace)"; in the first Jacoby collection among the unnamed material is a $\sigma^{7}$ with the same label; the middle anal segment is deeply concave placing the species in Baly's $\mathbf{A}_{\mathrm{A}}$.

Denticornis Blackb. seems to me to be the same as fraudulenta Jac. The peculiarities of the two first joints of the $\sigma^{7}$ antennæ described by Mr. Blackburn seem to me to be present in the $\sigma^{7}$ type of fraudulenta (in my collection) and to have been overlooked 
by Jacoby in his description; unless the specimen is held at a certain angle the points spoken of are easily overlooked.

Frontalis, Baly, l. c., p. 182, describes the third joint of the antennæ "twice as broad as long." Comparison with a specimen in my collection labeled "type ex Baly" seems to show the words to be accidentally transposed so they should read "twice as long as broad."

Borrei Baly (pectoralis Jac) is described as having the thorax impunctate (Ann. Mus. Gen. 1886, p. 50); the types now in my collection all have the surface near the anterior angles punctured, so the description should read, "impunctate except the anterior angles." Mr. Blackburn in describing his A. Richmondensis Proc. Zoöl. Soc. N. S. W. vol. v, 1890, p. 360, relies upon Mr. Jacoby's description to separate the two forms, which seem identical; in Mr. Jacoby's second collection he has under the name pectoralis specimens from N. S. W. (square purple label) which exactly agree with the description of Mr. Blackburn's species.

$A$. celebensis Jac. l. c., p. 52, typically has basal and ante-apical spots, what seems an extreme variety, has the elytra entirely black, except for a small flavous spot at the apex, or a slight margin in the middle of the side, the latter very like (flavo-marginata Duv.). All come from Toli-Toli, No. Celebes (Fruhstorfer).

Aulacophora blackburni sp. nov.

Reddish, castaneous, labrum, face and antennæ flavous, mandibles, eyes, tibiæ and tarsi blackish, femora fuscous at apex, the joints 3,4,5 of the antennæ dilated in the male like denticornis Jac.

Type: $1 \sigma^{\top}$ Manila (coll. Bowditch). Length, $5 \mathrm{~mm}$.

Head impunctate with two almost circular, deep fovæ, one on either side of the vertex above the eye, antennæ a little more than half the length of the body, first joint clavate, second joint very small, rounded, with a minute point externally in the middle, third joint in the shape of a long pointed perpendicular tooth, the following two joints broadly dilated acutely pointed at their anterior angles, the following joints elongate nearly equal, thorax twice as broad as long, finely punctured, very sparsely and finely on the disk, sulcation nearly straight, abbreviated on either side, elytra strongly depressed below the base, showing very lightly punctulate, last abdominal segment longitudinally lightly concave or sulcate.

The above specimen was in the second Jacoby collection mixed with examples of similis Oliv. Denticornis Jac. is the only other species known to me with the peculiar dentate antennal third joint, and this form should be placed next it. 
In Nov. Zoölog. vol. i, pp. 299-300, Mr. Jacoby described Oides unifasciata and suturalis, calling attention to the produced metasternum, imitating to some extent the genus Doryphora, four nearly allied additional forms have occurred and are here made known. Mr. Jacoby further intimates a new genus for his forms, but I have allowed all to remain in Oides for the present: the two Jacoby species and also the new ones are rather more chunky and robust than the other species of Oides and may be almost picked out by the shape alone.

\section{Oides confusus sp. nov.}

Convex ovate, shining; head, antennæ and below, mostly black, thorax flavous, elytra reddish fulvous, with a common broad basal black band, not attaining the lateral edge and a large round subapical spot on each elytron black.

$\uparrow$ with metasternum produced into a well marked obtuse process, last ventral segment obtuse, impressed on either side.

Type o Milne Bay, Br. N. Guinea (coll. Bowditch). Length, $12 \mathrm{~mm}$.

Imitates 0 . rubra Blanch. in size and color, but more convex and wider, antennæ attaining the rear edge of basal black band with the two or three basal joints more or less fulvous, third and fourth equal and longer than the others, head with a few fine punctures and an impressed line on the front, thorax very finely punctulate over its entire surface and all the angles rounded, scutellum smooth, truncate behind, elytra finely punctulate over the entire surface, abdomen edged with rufous spots, the coxæ and base of the femora are also more or less tinged with rufous, probably mixed with rubra in many collections.

Oides binotata sp. nov.

Convex, elongate, shining rufous, mouth, eyes, thorax and a large median lateral spot on each elytron black. $\sigma^{\top}$ and $\odot$ with metasternum produced into a wellmarked obtuse process.

Type: $\sigma^{7}$ ○ Kapour Holl, N. Guinea (Frühstorfer) coll. Bowditch. Length, $11 \mathrm{~mm}$.

Head with a few faint punctures on the front, which is smooth and shining with a faint median line, antennæ reaching the middle of the elytra, thorax shining, faintly impressed on either side, rather strongly, evenly punctured, sides strongly margined, the angles obtuse, the anterior ones slightly reflexed, scutellum with apex obtusely rounded, elytra smooth, shining, oblong, rather strongly and evenly punctate, the sutural margin somewhat thickened posteriorly, the black spot on each elytron is transversely rounded and a trifle nearer the lateral edge than the suture; the metasternum process, with the color easily separate this form.

Oides gahani sp. nov.

Ovate flavous, eyes, antennæ except base, elytra except anterior third, black, the flavous part of the elytra being narrowest at the scutel and from there curved back to meet the lateral margin at about the middle, $\sigma^{7}$ and $q$ with metasternum produced into a well marked obtuse process. 
$2 \sigma^{7} 1$ \& Stephansort, $1 \sigma^{7}$ Milne Bay, Br. N. Guinea. Length, $11 \mathrm{~mm}$.

Type: o Stephansort (coll. Bowditch).

Head faintly and sparingly punctulate with a dark median line, antennæ reaching the middle of the body the scape wholly and second joint partly flavous, thorax shining, impressed on either side of the disk, moderately and unevenly punctulate, obsolete at the sides, which are rounded and slightly reflexed, anterior angles rounded, posterior obtuse, scutel obtusely pointed behind, elytra shining, rather more strongly punctulate, near the base, punctures becoming obsolete and fine as they enter the black space, sutural margin thickened near the apex, entire underside dirty flavous; two of the specimens were in the $2 \mathrm{~d}$ Jacoby coll. under the name dimidiatum Blanch. but the size, shape and metasternal process separate it at once.

Oides femoratus sp. nov.

Smooth, convex, flavous, antennæ, most of the head, under side of the body largely and legs, except the basal two thirds of the femora black, scutellum and margin of the suture fuscous, $\sigma^{\top}$ with metasternum produced into a well marked obtuse process.

Type: $\sigma^{\text {T }}$ Cooktown (Austral.) (square dark blue paper label) 2 spec. (unnamed in $2 \mathrm{~d}$ Jacoby coll.) (coll. Bowditch). Length, $9 \mathrm{~mm}$.

Head with a few fine punctures and impressed line on the front like confusus (vide supra), mouth yellow, antennæ reaching the middle of body, the scape more or less rufous, thorax smooth, shining, faintly impressed on the disk, very faintly punctulate, anterior angles rounded, posterior obtuse, sides margined and faintly explanate, scutellum large very obtusely rounded at apex, elytra convex, everywhere faintly and evenly punctulate, the extreme sutural edge thickened, under side mostly shining black, with the pro and mesothorax somewhat flavous, and coxæ and trochanters more or less yellow, legs black except the basal two thirds of the femora; the color of the legs and the metosternal process (which is black) easily distinguish this form, the upper color makes the species resemble suturalis Jac. from New Guinea.

\title{
SOME COMMENTS ON THE VALUE OF WARNING COLORS AND MIMICRY IN INSECTS.
}

\author{
By C. H. Richardson,
} New Jersey Agricultural Experiment Station, New Brunswick, N. J.

During the course of an extended field trip through Nevada and eastern California several years ago, I had an opportunity to make some observations on the feeding habits of certain amphibians and reptiles. As several of these observations throw light upon the protective value of warning colors and mimicry in insects, they are given in the hope that they will be a real contribution, even though a meager one, to these disputed questions.

In the region about Pyramid Lake, Nev., the fleet-footed gridiron-tailed lizard (Callisaurus ventralis Hallowell) was very abun- 

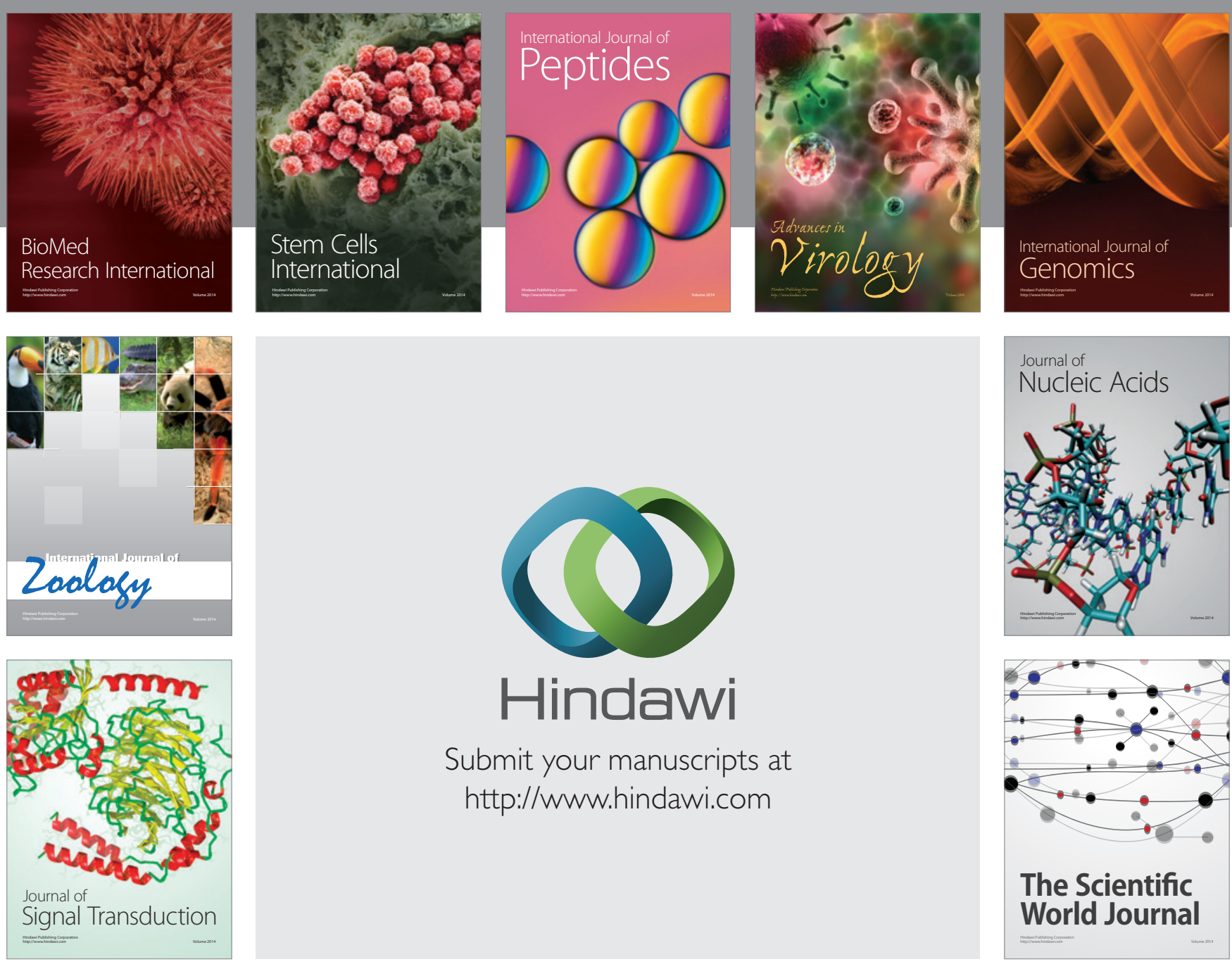

Submit your manuscripts at

http://www.hindawi.com
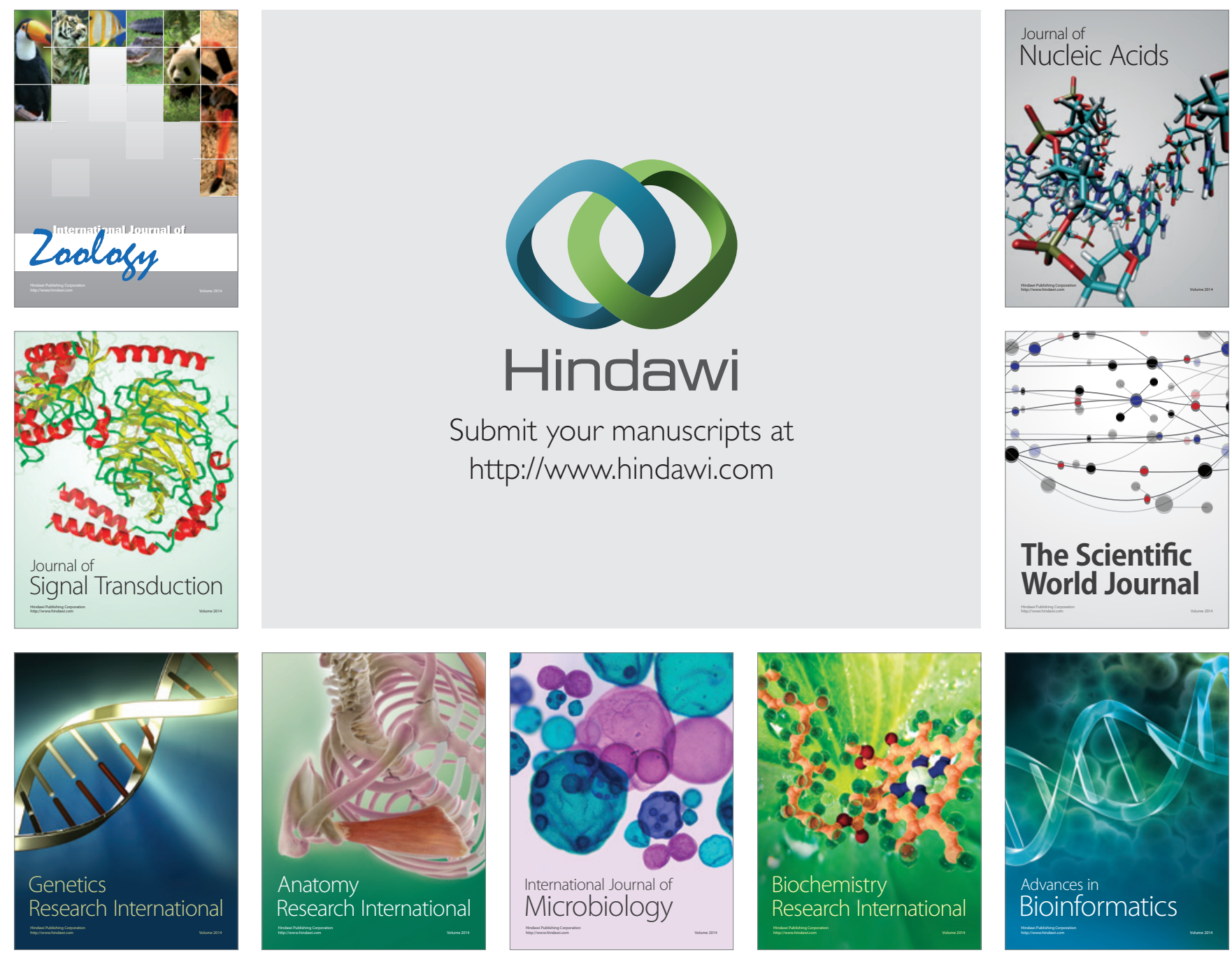

The Scientific World Journal
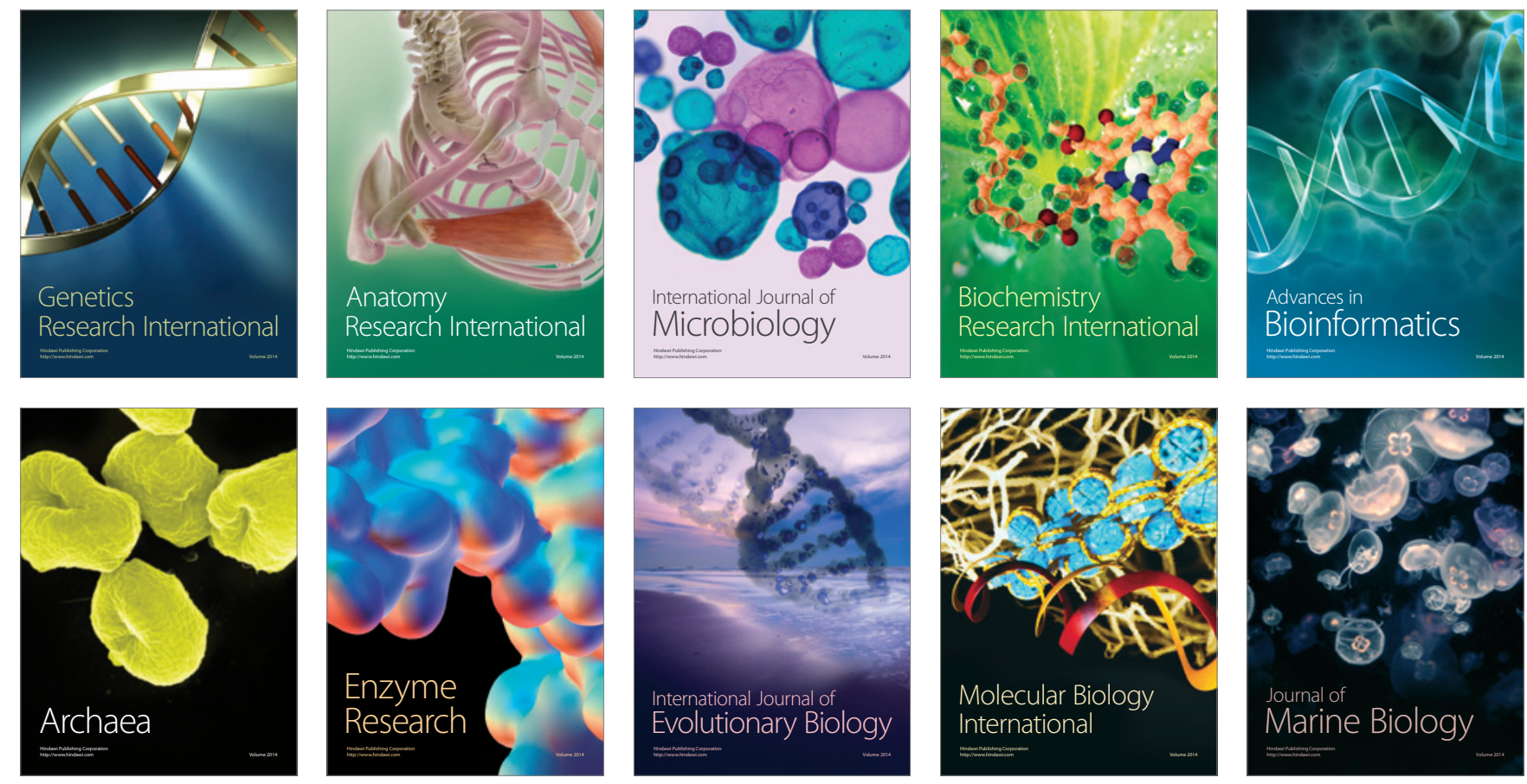